ske kvinder og røde plastikcurlers fra Ghana, var placeret en billedskærm, der fremviste en filmsekvens forestillende en mand der sminkes rødt $i$ ansigtet. Filmsekvensen understøttede og formidlede, at blodets farve rød konnoterer ritualer, magi, fødsel og død og andre liminale tilstande.

Rød er blod, tæthed, intimitet, kvindeskød og giftige pile. Rød er ikke bare rød. Rød er rød er rød. $\mathrm{Og}$ ting er ikke bare ting. Ting vidner og materialiserer kognitive positioner, samhandel, relationer, værdier og emotioner. Menneskets selv- og omverdensforståelse formes blandt andet gennem omgangen med hverdagens ting i hverdagens rum. Mennesker kan håndtere ting, men omvendt kan tingene også påvirke, hvordan individerne agerer, relaterer og føler. Objekterne og lokalerne er aktive medspillere, vi kan interagere emotionelt og intellektuelt med, hvorved de kommer til at indgå $i$ forskellige subjektiverings- og socialiseringsprocesser. Tingene og lokalerne bidrager altså afgørende, når mennesket udvikler forskellige kompetencer, identiteter og konceptuelle, sociale og praktiske færdigheder, deres udformninger kan opfordre til bestemte former for handlinger, og deres tilstedeværelse i vores daglige liv har stor indflydelse på vores kropslige erfaring af og omgang med omverden. Der er næppe tvivl om, at skaberne af denne udstilling har haft denne sans for materialitetens, tingens og handlingskontekstens mangfoldige betydning med sig, da de designede og udfyldte lokalerne. Så måske selv Kasper Utz ville have medgivet, at her døde de udstillede ting faktisk hverken af iltmangel, nedstirren eller mangel på berøring men fandt derimod deres egen poetiske livsform i montrernes egen form for magi.

Louise Fabian

Neurovidenskab. En udfordring
for filosofisk tcenkning Steen Nepper Larsen, GNOSIS, 186 sider, Tilgangelig som E-bog på wnw.gnosis. au.dk.

Udviklingen indenfor hjerneforskning sker tilsyneladende i rasende fart, hjulpet på vej af finansiel støtte, som humanister blot kan sukke misundeligt over. Uafladeligt hører man om, hvordan en ny følelse eller tankevirksomhed er lokaliseret til et bestemt område i hjernen, og for den uindviede forekommer det, at forskerne er snublende nær ved at afdække sandheder om mennesket, der reducerer os til skanningsresultater og grafer i et skema. Naturvidenskabsfolkene ler hånligt over de gammeldags filosoffer, der står og mumler forstyrret i skægget, mens de overhales indenom af reagensglas og hjerneskanninger. Og forsøger man at forsvare filosofien og anfægte naturvidenskabens krav på at kunne forklare alt, fremstår man som mørkemænd, og får evolutionsteorien smidt tilbage $\mathrm{i}$ hovedet: 
det er det sædvanlige; det er fordi I ikke forstår. Sådan er i hvert fald Steen Nepper Larsens udgangspunkt, og i det lys er det opløftende, at han forsøger at bygge bro imellem de to forskningsfelter.

Bogens projekt er at muliggøre en accept af neurovidenskaben som betydende, uden at overgive sig til et neurocentristisk krav på at kunne forklare alt om mennesket, og dermed efterlade filosofisk tænkning impotent. Så langt fremstår Larsens forehavende særdeles sympatisk og interessant.

Der er da også en del at hente i den lille bog, men læseren udsættes for en særdeles ujævn bumletur, inden man står af i den anden ende - noget klogere, inspireret, men også temmelig forvirret.

Umiddelbart er sproget behageligt ligetil, og man forledes til at tro, at bogen vil være letlæst. Men efterhånden som historien bevæger sig dybere ind $\mathrm{i}$ overvejelserne omkring tænkningens væsen, kompliceres teksten noget og får karakter af, at skribenten lader sine tanker falde uordentligt ned på papiret. Man træder som læser ind $i$ et sprogunivers, hvor ord som 'højniveau-mentalistisk' og 'visuelt-menikke-alene-på-kort-og-skærme-endsige-ud-af-vinduet-kiggende' bruges med tilsyneladende selvfølgelighed.

Samtidig savner man en klar struktur. Teksten er bygget op som en række overvejelser over forskellige positioner i debatten, præsenteret som resuméer af forskellige forfattere, der repræsenterer både naturvidenskabelige og filosofiske positioner. Så langt så godt, men der er stor forskel på, hvor relevante de forskellige afsnit forekommer. Det står ikke altid klart, præcist hvad der skulle vises $i$ et bestemt afsnit, ligesom det af og til er svært at finde afgrænsningen imellem hvad den refererede forfatter mener, og hvad Larsen selv mener.

Alligevel toner en grundlæggende position frem, der på én gang afviser neurovidenskabens krav på at kunne reducere tænkning til hjernen, og filosofiens dualistiske skelnen imellem jeg'et og kødet. At forstå hjernen som et kontroltårn, hvor tankerne bliver til uafhængigt af omverdenen, er ifølge Larsen naturvidenskabens måde at fortsætte den dualistiske traditions metafysik, idet der skelnes skarpt imellem hjernen på den ene side, $\mathrm{og}$ så alt det andet, som hjernen erfarer igennem sanserne. Så selvom hjerneforskningen som udgangspunkt afviser den filosofiske dualisme ved at inkarnere tænkningen, ligger den alligevel under for den, ved at insistere på at isolere tænkningen rumligt og adskille den fra omverdenen. Det understreges at denne skelnen er indgroet $i$ vores verdensbillede, og antydes at naturvidenskaben har arvet forestillingen direkte fra filosofien.

Brobygningsprojektet udfolder sig således som et simultant angreb på de to positioner der bygges bro imellem, men med tyngden lagt i udfaldene imod neurovidenskaben. Nep- 
per Larsen har som udgangspunkt en forståelse for, at neurovidenskaben bibringer noget interessant og vigtigt, men han mener, at der hersker en tendens til neurocentrisme, hvor feltet udstrækker sin indflydelse langt ud over, hvad den tekniske formåen berettiger til. Det sker når man reducerer tænkning, implicit mennesket, til hjerneprocesser, der kan måles og beskrives.

Der er to grundtræk i Larsens kritik: for det første er den indforståede dualisme forkert. For det andet inviterer forsøget på at forklare mennesket til determinisme. Hævder man at menneskets tænkning, overvejelser, handlinger kan reduceres til målbare fænomener, som er bestemt af kemiske forbindelser i hjernen, står det snublende nært, at samme handlinger i virkeligheden står udenfor vores kontrol. Det bliver ekstra farligt hvis det lykkes at reducere samme processer helt ned til DNA-materialet, der er hjernecellernes udgangspunkt. For så opstår for alvor muligheden for at afvise skyld med forsvaret: "det var ikke mig, det var min hjerne."

Larsen redder vores frihed ved for det første, oplagt, at anskueliggøre at hjernens processer er så komplekse i deres mangfoldighed og indbyrdes forbundethed, at det er det rene fantasteri at drømme om at kunne beskrive grundlaget for en handling i detaljer. Her synes Larsen at have et vægtigt argument imod neurofetichister, der på en gang besynger hjernens vidun- derlige kompleksitet og andres manglende forståelse af den, og samtidig med sikker stemmeføring udråber den til svaret på alle spørgsmål: "vi ved meget lidt om hjernen, men når vi lærer mere, vil den forklare alt."

Larsens andet forsvar imod determinisme er at søge hjælp i det, der er hans bogs gennemgående pointe: hjernen står ikke alene, isoleret fra omverdenen. Synapser, lyder kodeordet: neuronernes indbyrdes forbundethed, der er mere afgørende end neuronerne selv, og tillige omskiftelige - tilmed påvirkelige! Hjernen udvikler sig hele tiden, danner nye neuroner og skaber nye forbindelser imellem de eksisterende. Hjernen er plastisk, kompleks og ændres konstant af erfaringer og sanseindtryk. Det afgørende er, at hjernen ikke står alene som autonom årsag til handlinger. Hjernen er ikke kausalitetens begyndelse, men påvirkes selv af omverdenen og sociale indtryk. Vi er altså mere end vores DNA og kan ikke blot sige: "det var min hjerne, der gjorde det" fordi vi ikke blot er vores neuroner, men et produkt af de samme neuroners møde med social erfaring. Det virker bemærkelsesværdigt, at den selv samme socialiseringsteori, der i sin tid blev anklaget for at fritage os fra personligt ansvar (ved at vores handlinger til enhver tid kunne undskyldes med, at det var fordi vi blev slået som små), her bruges til at redde hjernen fra den samme anklage...

Synapserne og hjernens forbundethed med omverdenen fungerer 
langt bedre til at understrege Larsens hovedpointe, angrebet på dualismen. Skellet imellem hjernen og omverdenen opblødes ved at påvise, at hjernen ikke fungerer isoleret, men konstant er i samspil med omgivelserne. Neuronerne kan ikke forstås alene, men skal tænkes sammen med omverdenen, kroppen, sanseindtryk og social erfaring. Når vi insisterer på at forstå hjernen isoleret, begrænser vi samtidig mulighederne for at forstå den. Tænkning fremstår på denne måde som et langt mere komplekst fænomen end den forestilling om en datamaskine med processor og harddisk, der ligger så snublende nær i vore dage. Larsen trækker dog grænsen ved Douglas Hofstadters påstand at vores 'jeg' lever uden for os selv, og fortsætter med at eksistere efter vores død igennem den måde, vi påvirker hinanden.

Sådanne overvejelser er der dog også plads til, og der bruges ligeledes tid på en lidt vaklende diskussion af, hvordan vi eksisterer ud over vores hjerne, ved at tankerne selv transcenderer tid og sted. At vi kan tænke os andre steder hen og tænke frem og tilbage i tiden, virker ikke som et afgørende argument for, at tænkningen ikke foregår et bestemt sted og på et bestemt tidspunkt. Det særligt problematiske ved denne form for argumentation er, at man taler fuldstændigt forbi naturvidenskaben, som ellers skulle være samtalepartneren. Bedre virker det når Larsen refererer en intern kritik af neurovidenskaben, hvor en forsker hævder, at postulatet om at alverdens tankeprocesser kan knyttes til bestemte lokaliteter i hjernen er grundlæggende forfejlet. Atter fremstår hjernen som et mere komplekst instrument end forskerne kan håndtere, og forsøget på at skematisere og forenkle virker som et desperat forsøg på at reducere det uforståeligt komplekse til noget vi kan magte. Ironisk nok er det vores hjernes manglende evne til at forstå sin egen kompleksitet, der er på spil.

Stof til eftertanke er der nok af, men endelig afklaring gives ikke og er heller ikke tilsigtet. For som Larsen siger, er charmen ved det problematiske, at det er uløseligt. Derfor også irritationen over neurovidenskabens selvfede postulat om at kunne bringe os løsninger - det ville være så uendeligt kedeligt, hvis det lykkes.

Toke Rojgaard Nielsen

\section{Og så en ristet hot dog med det bele}

Peder Skyum-Nielsen: Arveguldet - Danskernes vardier, Syddansk Universitetsforlag 2006, 480 sider, $348 \mathrm{kr}$.

Peder Skyum Nielsen har i bogen "Arveguldet - danskernes værdier" forsøgt at uddestillere, hvad han mener er det inderste og ypperste danske, hvilket er det, som betegnelsen arveguldet dækker over. Der er lagt 